\title{
63. BENTHIC FORAMINIFERAL STRATIGRAPHY, EASTERN MARGIN, NAZCA PLATE
}

\author{
Johanna M. Resig, Hawaii Institute of Geophysics and Department of Geology \\ and Geophysics, University of Hawaii
}

\section{INTRODUCTION}

Assemblages of benthic foraminifera from two drill sites of DSDP Leg 34 were identified and used to interpret paleobathymetry. The sites were located on the eastern margin of the Nazca plate, approximately west and northwest of Callao, Peru, as follows:

\begin{tabular}{ccccc}
\hline Site & Location & $\begin{array}{c}\text { Water } \\
\text { Depth }\end{array}$ & $\begin{array}{c}\text { Penetration } \\
(\mathrm{m})\end{array}$ & $\begin{array}{c}\text { Basement } \\
\text { Age }\end{array}$ \\
\hline 320 & $9^{\circ} 00.40^{\prime} \mathrm{S} ;$ & 4487 & 111.5 & Late Oligocene \\
& $83^{\circ} 31.80^{\prime} \mathrm{W}$ & & & \\
321 & $12^{\circ} 01.29^{\prime} \mathrm{S} ;$ & 4827 & 134.5 & Late Eocene \\
& $81^{\circ} 54.24^{\prime} \mathrm{W}$ & & & \\
\hline
\end{tabular}

Benthic foraminiferal species were determined from examination of the entire sand fraction $(>62 \mu \mathrm{m})$ of the approximately $10-\mathrm{cc}$ samples. More than 500 specimens were recovered from most of the samples of material deposited above the calcite compensation depth (CCD), yielding what should be a representative sampling (Douglas, 1973). In some instances, these tests had been concentrated through selective solution of planktonics. However, a shortcoming of the small sample volume was that both large-sized species and agglutinates originating below the CCD were sparse, preventing an accurate assessment of the distribution of those forms.

Deep-sea benthic foraminiferal data are useful for various interpretive purposes. Widespread benthic species are potentially important age indices (Douglas, 1973; Berggren, 1972) that might supplement or replace the more readily dissolved planktonic indices. Their depth-habit affords a measure of paleobathymetry (Ingle, 1973) and complements the age-depth interpretation (Sclater et al., 1971) of plate evolution. An additional use of benthic foraminifera arises from the location of the drill sites on the eastern Nazca plate. Material displaced from the continental margin would spread out onto the plate were it not for the sediment trap created by the Peru-Chile Trench. The benthic assemblages of the deep borings can thus provide an indication of the previous existence of the trench. All of these aspects of the distribution of benthic foraminifera are explored in this report.

\section{GENERAL RESULTS}

A summary of the cored intervals and the distribution of benthic foraminifera are given in Figures 1 and 2. Stratigraphic age in each case was based upon planktonic foraminifera, as presented by Quilty, this volume.

The abundance of benthic specimens per 10-cc sample and the species diversity varied according to lithology. Foraminiferal-nannofossil ooze in the lower section at Site 320 (Figure 1) contained from about 600 to 2400 benthics per sample; nannofossil ooze in the lower sec- tion at Site 321 (Figure 2) contained about 500 to 1350 specimens per sample; and predominantly siliceous ooze and clay in the top sections of both sites contained less than 100 specimens per sample and were sometimes barren of all foraminifera. This amounts to about 85 specimens per gram of dry original sample for the nannofossil ooze (321-13-3) to generally less than one specimen per gram of dry siliceous clay (321-5-4).

Thirty-five to 45 species generally composed the assemblages of the calcareous ooze. The assemblages were dominated by two or three species which often composed 50\% of the population. Douglas (1973) noted similar dominance through the stratigraphic column of sites in the Central Pacific Basin. Although his data are not exactly comparable to those of the present study in that a slightly coarser size fraction $(>100 \mu \mathrm{m})$ was examined from a larger $(20-50 \mathrm{cc})$ sample, it is interesting to note that large-sized species were well represented in his material and that the diversity of the assemblages was twice as high as species diversity in the present study, whereas the number of specimens per sample was considerably lower. This suggests that the large components are particularly diverse. The apparently higher concentration of benthic tests on the eastern Nazca plate is probably at least partly due to the inclusion in the data of some specimens of serial morphology that are less than $100 \mu \mathrm{m}$ wide. But such forms do not compose the majority of the Nazca assemblages. Selective solution, which tends to concentrate benthics, might also contribute to the relatively high populations. Parker and Berger (1971) have found that well-preserved foraminiferal ooze generally contains less than $2 \%$ benthics and that assemblages resulting from the highest amounts of solution generally contain greater than $10 \%$ benthics. The high percentage of benthics in the Eocene and early Oligocene section at Site 321 , which occurs with numerous fish remains, indicates that the assemblage is residual. However, the greatest number of benthics per sample (320B-2-5), contributed less than $1 \%$ to the total foraminifera and cannot be attributed to selective solution. The elimination of selective solution as the basic cause of the larger benthic populations, in this instance, suggests a third possibility: that foraminiferal productivity was relatively high on the eastern Nazca plate. Although of some practical interest, this suggestion cannot be substantiated on the basis of the information presently available and clearly requires additional data.

\section{STRATIGRAPHIC DISTRIBUTION OF BENTHIC SPECIES}

Populations of deep-sea benthic foraminifera are conservative in that some of the components persist over long periods of time and others evolve slowly relative to the more shallow-dwelling species. This is in large part 

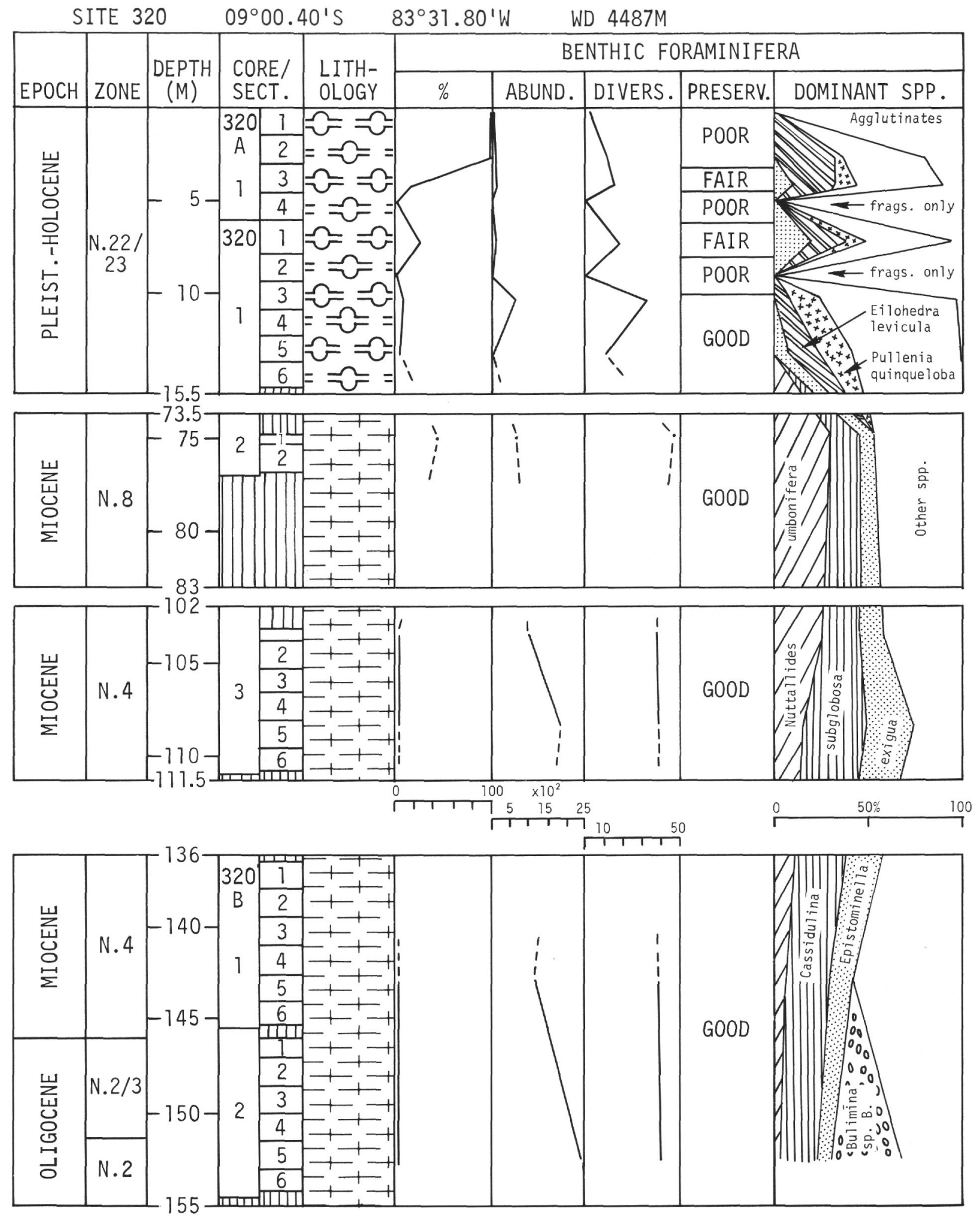

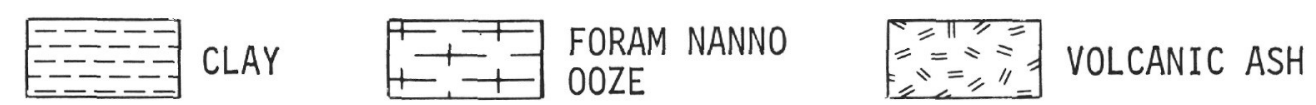

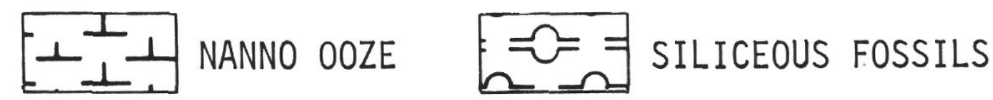

Figure 1. Core log and benthic foraminiferal data, Site 320. 

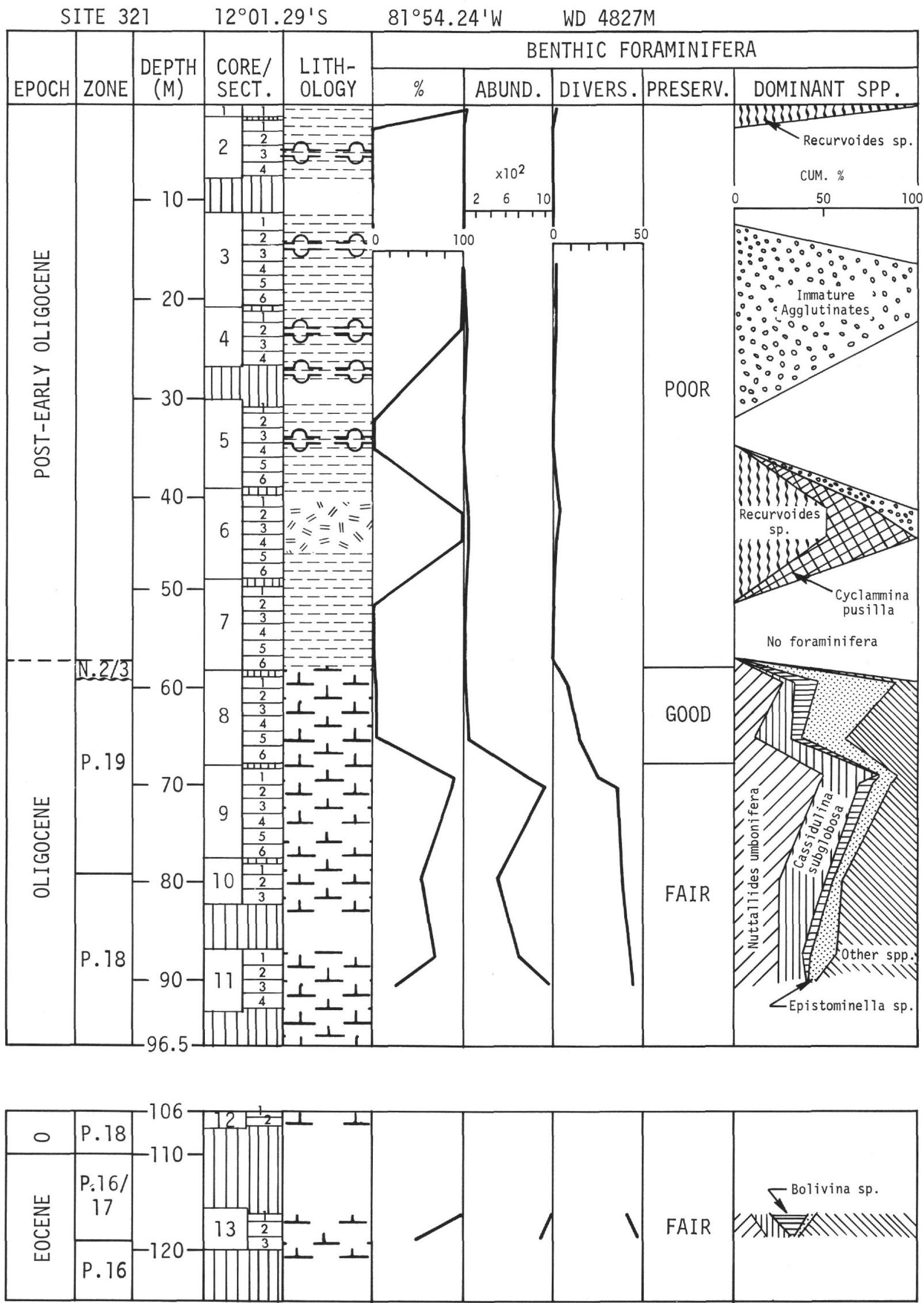

Figure 2. Core log and benthic foraminiferal data, Site 321. 
due to the general stability of the environment. However, a major decrease in the temperature of the bottom water mass from about $12^{\circ} \mathrm{C}$ to about $6^{\circ} \mathrm{C}$ in late Eocene-early Oligocene time and a further temperature decline following a peak of about $8^{\circ} \mathrm{C}$ in middle Miocene time (Douglas and Savin, 1973) are thought to have initiated benthic faunal changes in the Central Pacific (Douglas, 1973). Corresponding faunal changes also appear to have occurred on the eastern Nazca plate, as far as sampling interval and faunal preservation permit comparison.

The occurrences and relative abundances of benthic species at Sites 320 and 321 are given in Table 1, and select species are illustrated on Plates 1-4. Toward the end of the early Oligocene, a faunal break is evidenced by the extinction of six species at or just below the break and the first appearance of seven species above the break. Numerous species disappear locally at Site 321, and the much reduced population consists of very small specimens among the planktonic as well as the benthic species. Following the break, late Oligocene and early Miocene faunas are similar in species composition. Genera which are common in the late Eocene to early Miocene section are Cassidulina, Nuttallides, Bulimina, Cibicidoides, Gyroidina, Pleurostomella and Stilostomella. Heronallenia lingulata (Plate 3, Figures 4 and 5 ) is a rather conspicuous element of these faunas. The modern fauna, characterized by Cassidulinoides, Eilohedra, Melonis, and abundant Pullenia, has been noted to arise in middle Miocene time (Berggren, 1972; Douglas, 1973), but this interval was not sampled or was poorly preserved on the eastern Nazca plate. The genera Epistominella and Oridorsalis are not restricted in their distribution, being prominent throughout the section.

Certain species are defined as indices by their stratigraphic ranges in the early, calcareous portion of the section at both sites. Some of these species have been reported elsewhere in strata of comparable age, and others are apparently undescribed forms that occur fre- quently and have limited stratigraphic ranges on the Nazca plate (Table 2).

Eocene indices include Alabamina dissonata, Asterigerina crassaformis and Nuttallides truempyi. $A$. dissonata and $N$. truempyi are distributed widely, e.g., Central Pacific (Douglas, 1973) and Atlantic (Beckmann, 1954; Berggren, 1972), where N. truempyi occurs as far north as the Labrador Sea (Berggren, 1972). Specimens appearing to be Asterigerina crassaformis have been reported from the eastern Pacific border: The Olympic Peninsula of Washington (Rau, 1964), the California Coast Ranges (reviewed by Mallory, 1959), Ecuador (Cushman and Stainforth, 1951), and Peru (Cushman and Stone, 1949). R. Douglas (personal communication) noted some specimens in the Central Pacific that might be assigned to the species. However, because of the similarity in form between $N$. truempyi and $A$. crassaformis, it is clear that a reassessment of the identification of $A$. crassaformis must be made before conclusions can be drawn regarding its distribution. In the Nazca material, the two species have been differentiated according to several criteria (compare Plate 3, Figures 8, 9 and 10, 11).

In addition to these widely recognized species, some apparently new species were found to occur frequently in the Eocene to early Oligocene section at Site 321. These species include a small and ornate Bolivina sp. (Plate 2, Figures 1-3), a compressed planispiral form, possibly in the genus Allomorphinella (Plate 4, Figures 57), and two finely agglutinated forms that may present some variation of the genus Cystammina (Plate 1, Figures 1-3 and 4-7). A small and partially costate Bulimina sp. B (Plate 2, Figure 6) occurs in the Oligocene to early Miocene section. All of these species are mentioned here because they are abundant and conspicuous faunal elements.

Some of the selected biostratigraphic indices have ranges on the Nazca plate that are at variance with those reported in the literature. Small sample size is probably

TABLE 1

Stratigraphic Occurrence of Benthic Foraminiferal Species

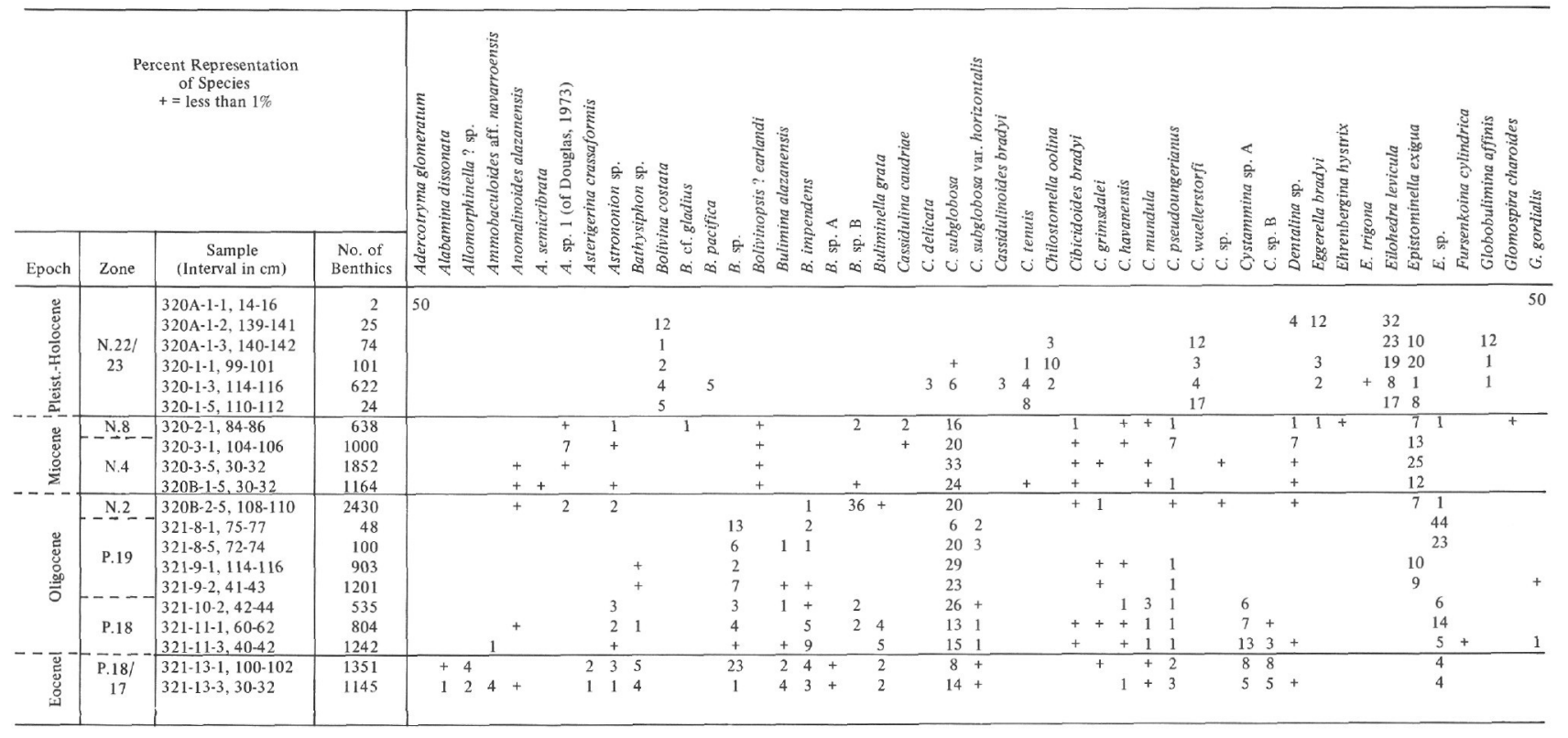


responsible for the more restricted occurrence of rare species such as Anomalinoides semicribrata and Martinottiella petrosa. Cibicidoides havanensis (Plate 4, Figures 3 and 4) and Anomalinoides sp. 1 (Plate 4, Figures 10 and 11) have longer ranges than previously reported, extending into the Miocene. The consistency of the planktonic faunas from these samples indicates that reworking has not caused these extended ranges.

The Verdun, Kreyenhagen, Oceanic and Cipero formations all show faunal similarity to parts of the late Eocene to early Miocene sequence at Sites 320-321. In addition to correlative species, the general aspect of all of these faunas is one in which pleurostomellids, stilostomellids, and pyrulinids are conspicuous, along with long-ranging forms which have some environmental significance.

\section{PALEOBATHYMETRY}

This report follows the usage of Hedgpeth (1957) in defining the bathymetric regions of the marine basin lying deeper than the continental or insular shelves, wherein "bathyal" signifies the slope, from 200 to 4000 meters water depth and "abyssal" the deep sea floor between 4000 and 6000 meters water depth. In low to mid latitudes, benthic faunas of the upper bathyal regions (less than $1000 \mathrm{~m}$ ) live under the influence of the thermocline whereas deeper lying faunas are adapted to relatively stable temperatures that are $5^{\circ} \mathrm{C}$ or less in the modern ocean (Phleger, 1960). The calcite compensation depth (CCD) currently lies at about 4000 meters on the eastern Nazca plate (Kulm et al., 1974), dividing the bathyal and abyssal benthos.

Modern benthic foraminiferal assemblages of the mid to low latitude eastern Pacific have been analyzed in several studies that collectively cover the gamut of bathymetry. Inspection of the ranges of faunal components allows certain generalizations to be made regarding the nature of assemblages peculiar to the various bathymetric realms. In the shelf assemblages, the genera Buccella, Buliminella, Eponides, and Nonionella are conspicuous elements (Cushman and Kellett, 1929; Boltovskoy and Theyer, 1970), with Valvulineria becoming important on the outer shelf (Bandy and Rodolfo, 1964; Boltovskoy and Theyer, 1970). Upper bathyal assemblages are dominated by various species of Bolivina-Brizalina, Cassidulina, Epistominella and costate Uvigerina (Bandy and Arnal, 1957). In order to more directly relate these literature reports to the present study, two Hawaii Institute of Geophysics samples from upper bathyal depths approximating the DSDP borings in latitude were analyzed. The foraminiferal assemblages in those samples (Figure 3 ) agreed with the previous reports.

All of these relatively shallow-water representatives are potential indicators of downslope displacement of sediment. Some of them have been identified in Recent and Pleistocene sediments of the Peru-Chile Trench system (Bandy and Rodolfo, 1964). Prince et al. (1974) report Quaternary turbidites of landward origin on the margin of the plate above the present trench floor. But in this tectonically active region, relative displacement of a portion of the trench system is implied rather than non existence of a sediment trap.

Information regarding the existence of the Peru-Chile Trench can be derived from the composition of the benthic assemblages of the Nazca borings (Table 1), specifically in the upper part of the stratigraphic section that was deposited as the drill sites approached the eastern margin of the plate. None of the shelf or upper slope species or their morphological counterparts were noted in the samples from Sites 320 and 321. The significance is twofold: (1) the sites were removed or isolated from the continent or other topographic highs that might contribute exogenous sediment and (2) deposition of the section took place at lower bathyal to abyssal depths at both sites. Although based upon limited sampling, the data suggest the existence of the

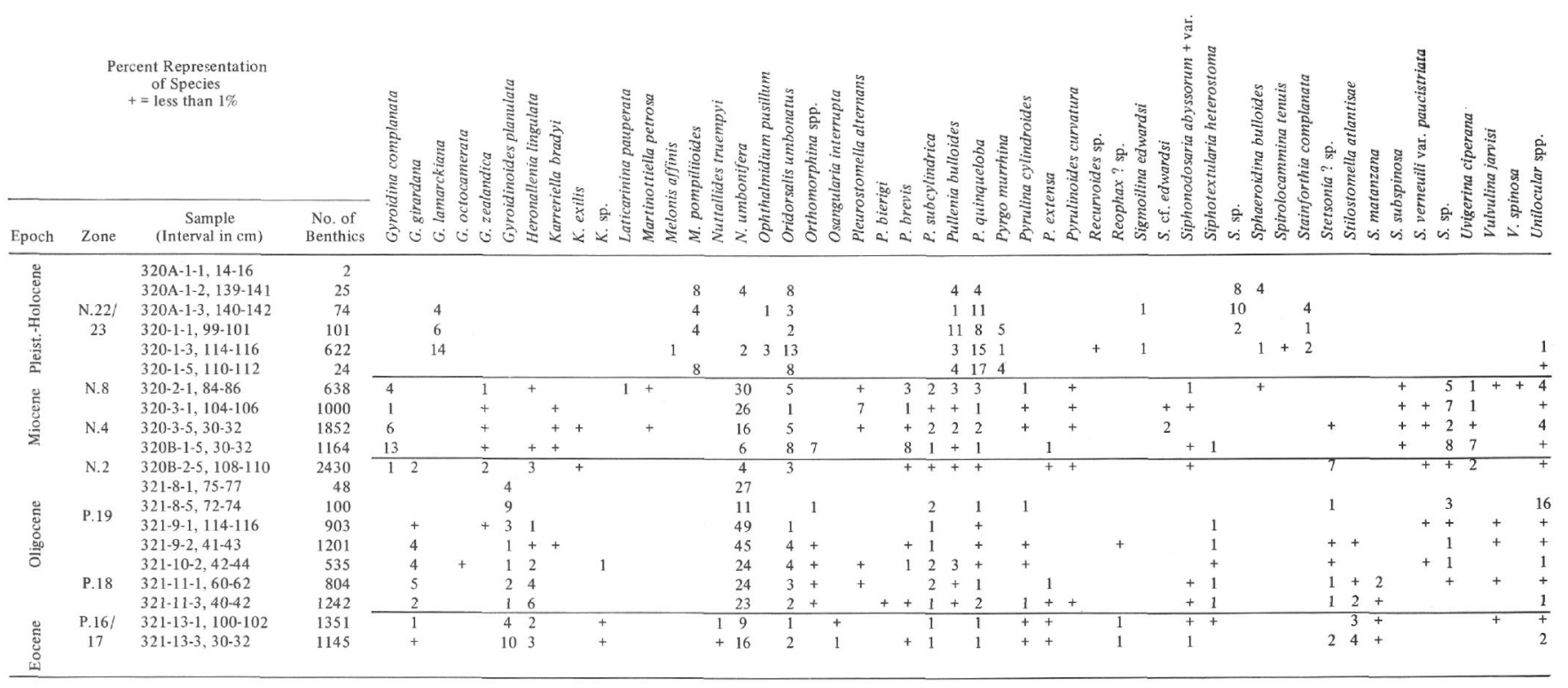


TABLE 2

Range and Correlation of Stratigraphic Index Species

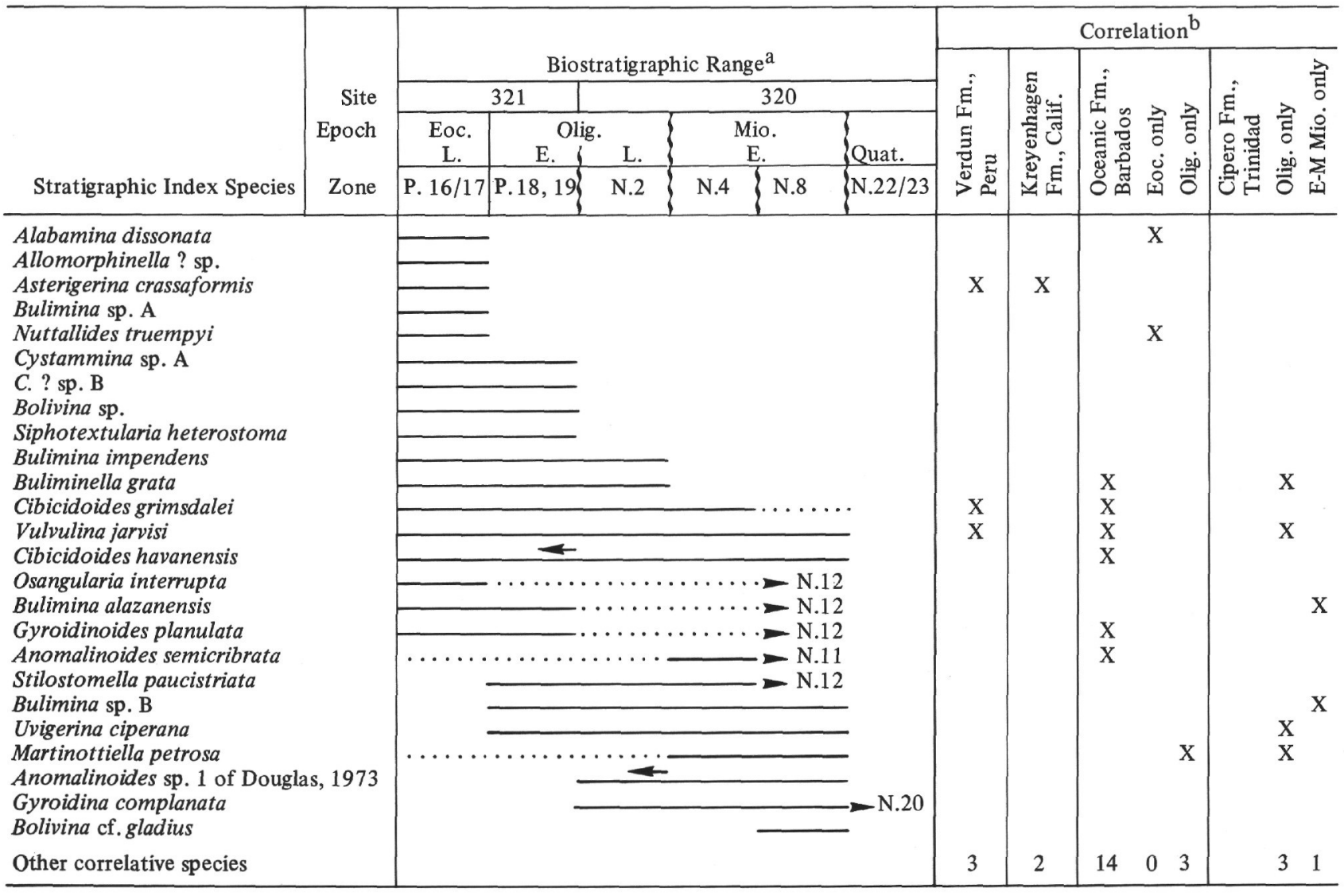

a Dotted line indicates comprehensive range, including occurrences in other areas. Arrow denotes limit of range in other areas.

${ }^{b}$ Cushman and Stone, 1949 (Verdun); Cushman and Siegfus, 1942 (Kreyenhagen); Beckmann, 1954 (Oceanic); Cushman and Stainforth, 1945 (Cipera).

KK71 GC3

$12^{\circ} 23.448^{\prime} \mathrm{S} ; 77^{\circ} 29.277^{\prime} \mathrm{W}$

W.D. $363 \mathrm{~m}$

$99 \%$ Benthics

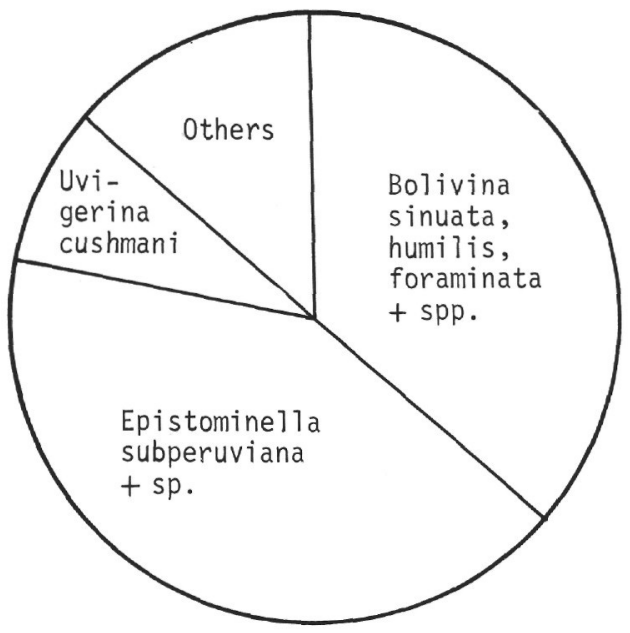

KK71 GC2

$12^{\circ} 29.139^{\prime} \mathrm{S} ; 77^{\circ} 35.843^{\prime} \mathrm{W}$

W.D. $632 \mathrm{~m}$

$80 \%$ Benthics

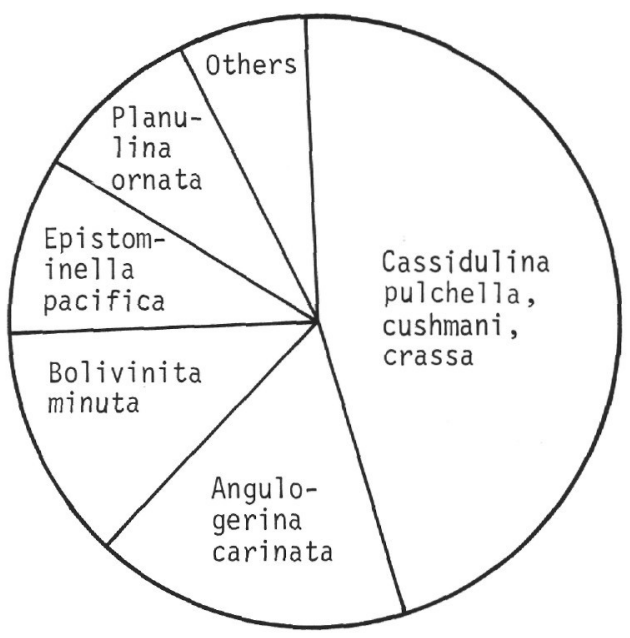

Figure 3. Composition of upper bathyal benthic faunas. 
trench from at least the later part of the Tertiary period. Most researchers attempting a bathymetric relegation of deep-sea species (Bandy and Echols, 1964; LeR oy and Levinson, 1974) find the absolute range to be great, but the range of abundance to be somewhat more restricted and vastly more informative. The ultimate approach is to isolate bathymetric assemblages through factor analysis, which gives promise of refining resolution in the lower bathyal and abyssal realms. Thus, Streeter (1973) was able to subdivide deep Atlantic benthos into an ? Epistominella $(=$ Nuttallides) umbonifera assemblage, mostly monospecific, in greater than 4000 meters depth and a Cibicides (=Cibicidoides) wuellerstorfiEpistominella exigua assemblage between 2500 and 4000 meters, based on abundances. A second complication affecting bathymetric analysis involves the tendency for many species to follow water masses rather than bathymetry (Streeter, 1973) and other species to remain "isobathyal" under diverse conditions (Bandy and Echols, 1964). An attempt was made to circumvent this problem by ignoring data from the latitudinal extremes and by otherwise considering the composite range of reported greatest abundance as a valid maximum range for moderate to large populations of the species in the study area. Past changes in the characteristics of the bottom water mass (Douglas and Savin, 1973) might have caused some of the species to migrate to depths other than those they presently prefer. But this factor is considered of secondary importance here, as it will be shown that the conservative elements of the Nazca faunas are generally consistent with the picture of a progressively subsiding sea floor.

Species selected as reliable indicators of bathymetry were those that persisted throughout the calcareous portion of the stratigraphic sections and were also generally the most abundant species, as well as several others that have been used as indices in other studies. The modern depth ranges of these species and their abundance and distribution in the cores is presented in Figure 4. The suite of species is indicative of the fairly uniform environment below 1000 meters. Epistominella exigua and Cibicidoides wuellerstorfi suggest depths in excess of 2500 meters, and Nuttallides umbonifera is most abundant in lowest bathyal to abyssal depths. It may be noted that the relative percent of Nuttallides, which in this case is also indicative of abundance, increases from Zone P.16/17 to the lower part of Zone P.19 at Site 321 and from Zone N.2 to Zone N.8 at Site 320, suggesting subsidence of the sea floor toward abyssa! depths in these intervals. The late part of the early Oligocene at Site 321 is characterized by a peculiar fauna of very small benthic and planktonic specimens that is somewhat anomalous to the general trend. This fauna may reflect the effect of the post-Eocene temperature drop. The Quaternary foraminifera at Site 320 alternate between agglutinated faunas and calcareous faunas of lower bathyal-abyssal aspect. This calcareous material did not originate on the continental side of the PeruChile Trench, according to the absence of displaced species from the shelf and upper slope, and no local elevations with relief greater than about 150 meters were indicated by the bottom profiler, so that a local source for displaced calcareous tests also seems unlikely. Elimination of displacement as the source of the calcareous faunas lends credence to the notion that they are in situ assemblages that existed during times of lower CCD levels, perhaps associated with the glacialinterglacial cycles. These bathymetric interpretations based on benthic foraminifera agree well with paleodepth curves (Figure 4) constructed according to the nomogram of Berger (1973), based on crustal age and depth (Sclater et al., 1971).

\section{DISCUSSION}

The two sites exhibit similar succession of benthic foraminiferal faunas recording increasing bathymetry and proceeding as follows:

Phase I-Abundant and diverse calcareous benthic faunas characteristic of bathyal depths below the thermocline. At Site 320, deposition occurred above the foraminiferal lysocline and benthics are less than $1 \%$ of the total foraminifera. At Site 321, deposition was controlled by a shallow CCD in late Eocene time (Berger, 1973; Van Andel and Moore, 1974), and high percentage of benthics suggests strong dissolution of foraminiferal deposits.

Phase II-A shift toward calcareous species that are most abundant in the lower bathyal to abyssal environment. At Site 320 , this is accompanied by an increase in the relative proportion of benthic to planktonic foraminifera and a decrease in the absolute abundance of foraminiferal specimens, reflecting selective solution.

Phase III-Abyssal agglutinated faunas in which abundance and diversity of specimens is low due to poor preservation below the CCD.

Litho- and biostratigraphy indicate that Site 321 passed beneath the CCD in late Oligocene time and remained there subsequently. According to the paleodepth curve (Berger, 1973; Sclater et al., 1971; Figure 4), this would place the local CCD at a depth of about 4000 meters in the late Oligocene. Site 320, which lies about 400 meters shallower than Site 321 , experienced a more complex history, as calcareous tests of bathyal to abyssal species in various horizons of the Quaternary section indicate that it did not remain below the CCD in its later history. A critical portion of the section in determining relationships to the CCD was not cored. However, the poor representation of planktonic foraminifera in the early Miocene (N.8) portion of the section suggests that deposition occurred near the CCD at that time. The water depth for that deposit attained through backtracking is also about 4000 meters. The 4000 meter depth is again repeated as the modern CCD in the area (Kulm et al., 1974).

Although there is thus some basis for regarding the post-Eocene CCD as approximately static in the area, a critical portion of the section remains unsampled and there are indications of fluctuations of the CCD during the Quaternary at Site 320. From data of other DSDP sites, Berger (1973) defines the CCD at about 4000 meters in post Eocene time at $12^{\circ} \mathrm{S}$ in the Pacific. Van Andel and Moore (1974) concur with this level in data they present for the Miocene epoch at the same latitude. The CCD curves in both cases have been smoothed over to eliminate short-term fluctuations. However, judging from the overall record, which includes more than 1000 meters of vertical displacement of the CCD in late Eocene-early Oligocene time, it is not unreasonable to assume that such fluctuations might involve up to 500 meters of displacement, which would allow calcareous 


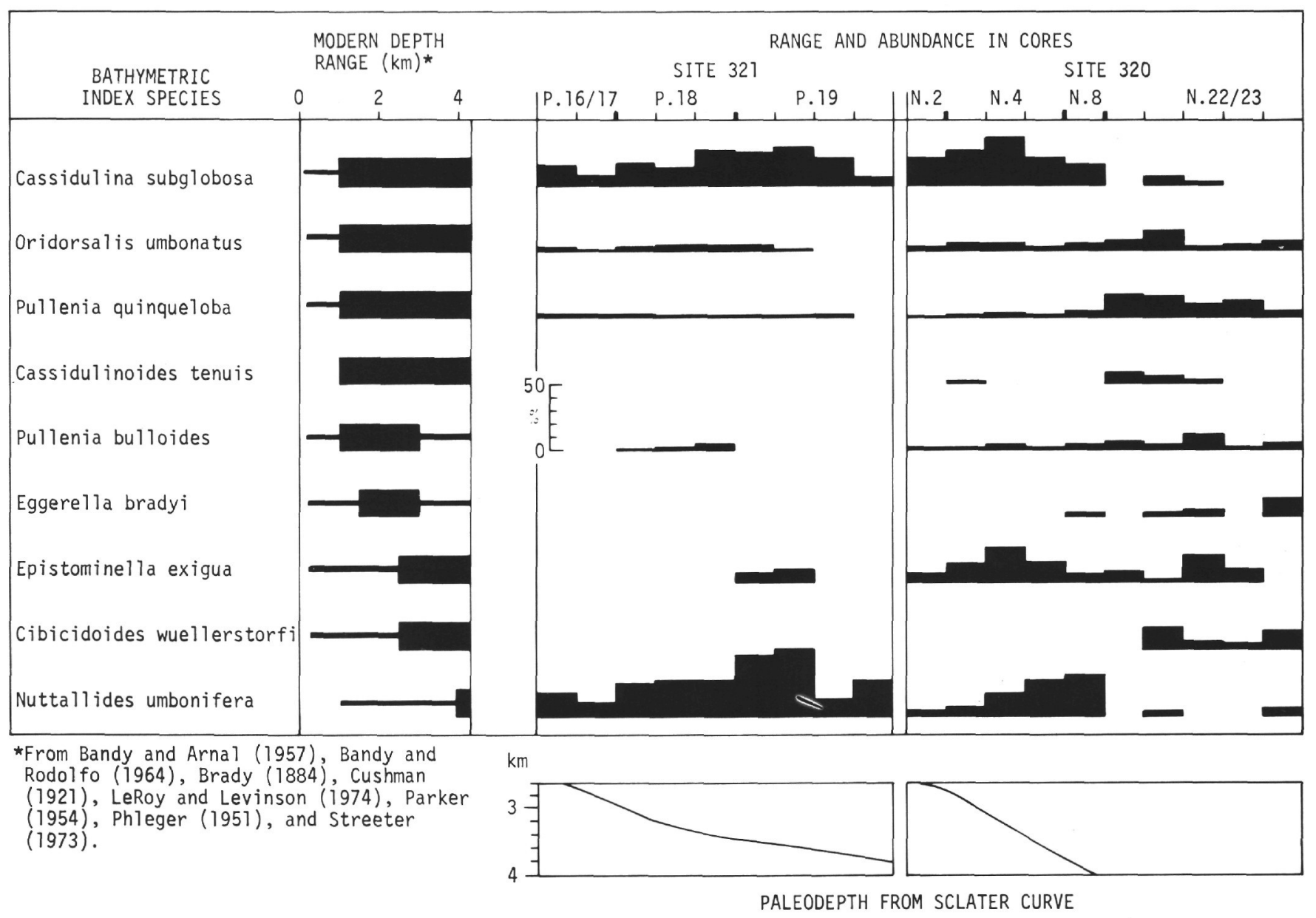

Figure 4. Distribution of bathymetric index species.

assemblages in the younger section at Site 320 . Such fluctuations did not affect Site 321 , about 400 meters deeper.

\section{ACKNOWLEDGMENTS}

This work was supported by National Science Foundation Grant IDO71-04207-A04, under the IDOE Nazca Plate Project. The photomicrographs were taken by Karen Margolis with a Cambridge S-140 Scanning Electron Microscope (National Science Foundation Grant GD-34270). William Coulbourn reviewed the manuscript. This is Hawaii Institute of Geophysics Contribution No. 721.

\section{REFERENCES}

Bandy, O.L. and Arnal, R., 1957. Distribution of Recent foraminifera off west coast of Central America: Am. Assoc. Petrol. Geol. Bull., v. 41, p. 2037-2053.

Bandy, O.L. and Echols, R.J., 1964. Antarctic foraminiferal zonation: Am. Geophys. Union Antarctic Res. Ser., v. 1, p. 73-91.

Bandy, O.L. and Rodolfo, K., 1964. Distribution of foraminifera and sediments, Peru-Chile Trench area: DeepSea Res., v. 11, p. 817-837.

Beckmann, J.P., 1954. Die Foraminiferen der Oceanic Formation (Eocaen-Oligocaen) von Barbados, Kl. Antillen.: Eclog. Geol. Helv., v. 46, p. 301-412.

Berger, W.H., 1973. Cenozoic sedimentation in the eastern tropical Pacific: Geol. Soc. Am. Bull., v. 84, p. 1941-1954.
Berggren, W.A., 1972. Cenozoic biostratigraphy and paleobiogeography of the North Atlantic. In Laughton A.S., Berggren, W.A., et al., Initial Reports of the Deep Sea Drilling Project, Volume 12: Washington (U.S. Government Printing Office), p. 965-1001.

Boltovskoy, E. and Theyer, F., 1970. Foraminiferos Recientes de Chile Central: Rev. Mus. Argentino Cienc. Nat. Hidrobiol. v. 2, p. 279-379.

Brady, H.B., 1884. Report on the foraminifera dredged by H.M.S. Challenger, during the years 1873-1876: Rept. Voy. Challenger, Zool., v. 9, p. 1-814.

Cushman, J.A., 1921. Foraminifera of the Philippine and adjacent seas: U.S. Nat. Mus. Bull., v. 100, p. 1-608.

Cushman, J.A. and Kellett, B., 1929. Recent foraminifera from the west coast of South America: U.S. Nat. Mus. Proc., v. 75, Art. 25, p. 1-16.

Cushman, J.A. and Siegfus, S.S., 1942. Foraminifera from the type area of the Kreyenhagen Shale of California: San Diego Soc. Nat. Hist., Trans., v. 9, p. 385-426.

Cushman, J.A. and Stainforth, R.M., 1945. The foraminifera of the Cipero Marl Formation of Trinidad, B.W.I.: Cushman Lab. Foram. Res. Spec. Pub., v. 14, p. 3175.

Cushman, J.A. and Stainforth, R.M., 1951. Tertiary foraminifera of coastal Ecuador: Part I, Eocene: J. Paleontol., v. 25 , p. 129-164.

Cushman, J.A. and Stone, B., 1949. Foraminifera from the Eocene Verdun Formation, of Peru: Contrib. Cushman Lab. Foram. Res., v. 25 , p. 73-84.

Douglas, R.G., 1973. Benthonic foraminiferal biostratigraphy in the central north Pacific, Leg 17, Deep Sea Drilling Project. In Winterer, E.L., Ewing, J.I., et al., Initial 
Reports of the Deep Sea Drilling Project, Volume 17: Washington (U.S. Government Printing Office), p. 607671.

Douglas, R.G. and Savin, S.M., 1973. Oxygen and carbon isotope analyses of Cretaceous and Tertiary foraminifera from the central North Pacific. In Winterer, E.L., Ewing, J.I., et al., Initial Reports of the Deep Sea Drilling Project, Volume 17: Washington (U.S. Government Printing Office), p. 591-605.

Hedgpeth, J.W., 1957. Classification of marine environments: Geol. Soc. Am. Mem. 67, v. 1, p. 17-27.

Ingle, J.C., Jr., 1973. Neogene foraminifera from the northeastern Pacific Ocean, Leg 18, Deep Sea Drilling Project. In Kulm, L.D., von Huene, R., et al., Initial Reports of the Deep Sea Drilling Project, Volume 18: Washington (U.S. Government Printing Office), p. 517-567.

Kulm, L.D., Resig, J.M., Moore, T.C., Jr., and Rosato, V.J., 1974. Transfer of Nazca Ridge pelagic sediments to the Peru continental margin: Geol. Soc. Am. Bull., v. 85, p. 769-780.

LeRoy, D.O. and Levinson, S.A., 1974. A deep-water Pleistocene microfossil assemblage from a well in the northern Gulf of Mexico: Micropaleontology, v. 20, p. 137.

Mallory, V.S., 1959. Lower Tertiary biostratigraphy of the California Coast Ranges: Am. Assoc. Petrol. Geol., Tulsa, Okla., p. 1-416.

Parker, F.L., 1954. Distribution of the foraminifera in the northeastern Gulf of Mexico: Harvard Coll. Mus. Comp. Zool. Bull., v. 111, p. 453-588.
Parker, F.L., 1964. Foraminifera from the experimental Mohole drilling near Guadalupe Island Mexico: J. Paleontol., v. 38, p. 617-636.

Parker, F.L. and Berger, W.H., 1971. Faunal and solution patterns of planktonic foraminifera in surface sediments of the South Pacific: Deep-Sea Res., v. 18, p. 73-107.

Phleger, F.B., 1951. Ecology of foraminifera, northwest Gulf of Mexico, Part I. Foraminifera distribution: Geol. Soc. Am. Mem., v. 46, p. 1-88.

Phleger, F.B., 1960. Ecology and distribution of Recent foraminifera: Baltimore (John Hopkins Press), p. 1-297.

Prince, R.A., Resig, J.M., Kulm, L.D., and Moore, T.C., Jr., 1974. Uplifted turbidite basins on the seaward wall of the Peru Trench: Geology, v. 2, p. 607-611.

Ramsay, A.T.S., 1974. The distribution of calcium carbonate in deep sea sediments: Soc. Econ. Paleontol. Mineral. Spec. Pub., v. 20, p. 58-76.

Rau, W.W., 1964. Foraminifera from the northern Olympic Peninsula, Washington: U.S. Geol. Surv. Prof. Paper 374G, p. 1-33.

Sclater, J.G., Anderson, R. N., and Bell, M.L., 1971. Elevation of ridges and evolution of the central eastern Pacific: J. Geophys. Res. v. 76, p. 7888-7915.

Streeter, S.S., 1973. Bottom water and benthonic foraminifera in the North Atlantic-glacial-interglacial contrasts: Quaternary Res., v. 3, p. 131-141.

Van Andel, T.H. and Moore, T.C., Jr., 1974. Cenozoic calcium carbonate distribution and calcite compensation depth in the central equatorial Pacific Ocean: Geology, v. 2, p. 87-92. 


\section{PLATE 1}

Figures 1-3 Cystammina? sp. A, Sample 321-13-1, 100-102 cm, late Eocene. This species and the following one that appears to be derived from it are tentatively identified as belonging to the genus Cystammina, but probably represent a new genus or two new genera. The trochospiral test is finely agglutinated, with considerable cement, particularly in the earlier chambers. Species A has 3 or $3^{1 / 2}$ chambers in the final volution, with the sutures depressed and curved. The aperture is on the ventral margin, almost peripheral in position. It is a low arch, above the base of the chamber under a projection of the wall, as in Cystammina galeata (Brady). The range of this species is late Eocene to earliest Oligocene in the Nazca section.

1. Dorsal view, maximum diameter $0.18 \mathrm{~mm}$.

2. Ventral view, maximum diameter $0.19 \mathrm{~mm}$.

3. Enlarged segment of wall of ventral side, $x$

Figures 4-7 Cystammina? sp. B, Sample 321-13-3, 30-32 cm, late Eocene. This species appears to present a progression in the development of the above species in which the aperture, still located under a projection, has moved to the dorsal side. There are three of four chambers in the final volution and the sutures are straight on the ventral side, although curved dorsally. Species B ranges from late Eocene to earliest Oligocene on the Nazca plate.

4. Dorsal view, maximum diameter $0.25 \mathrm{~mm}$.

5. Edge view, dorsal side to right, maximum diameter $0.18 \mathrm{~mm}$.

6. Ventral view, maximum diameter $0.23 \mathrm{~mm}$.

7. Enlarged segment of wall of ventral side, $\times 1140$.

Figure $8 \quad$ Siphotextularia heterostoma (Fornasini), Sample 321-13-1, 100-102 cm, late Eocene. Length of specimen $0.21 \mathrm{~mm}$. 
PLATE 1
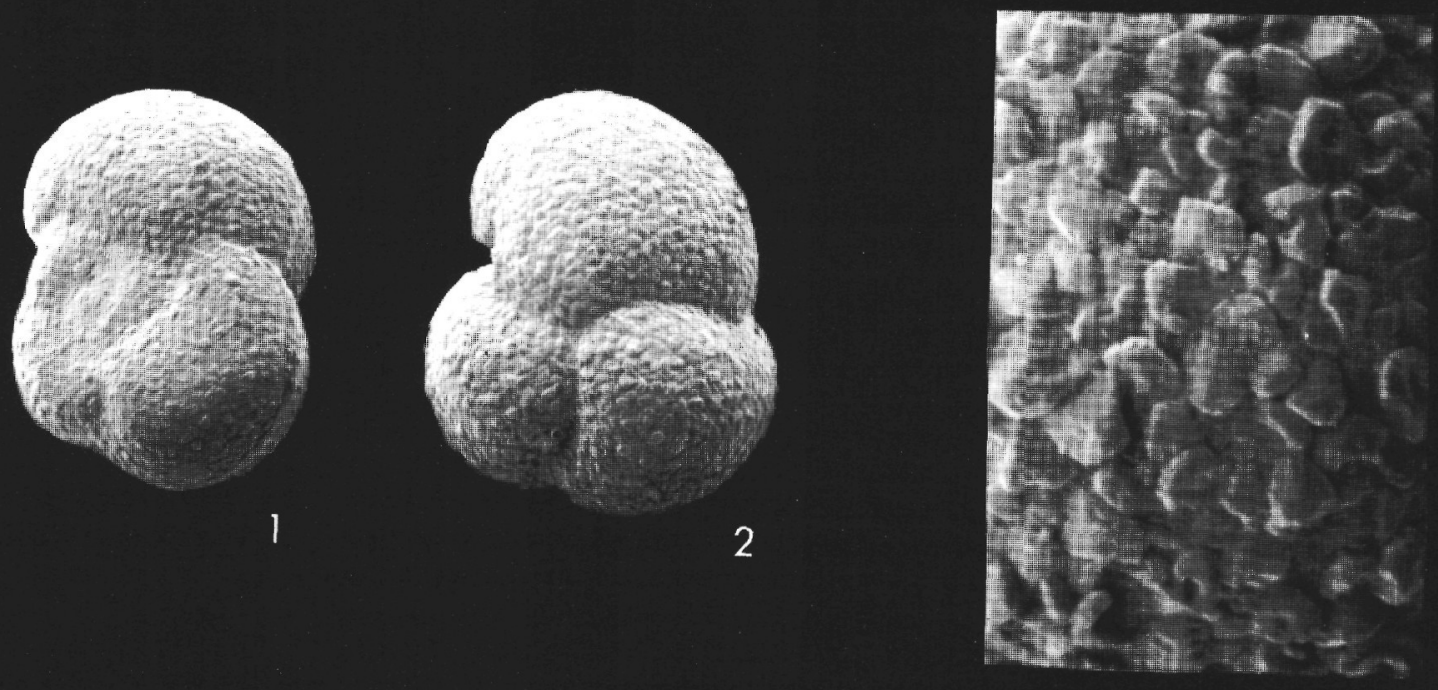

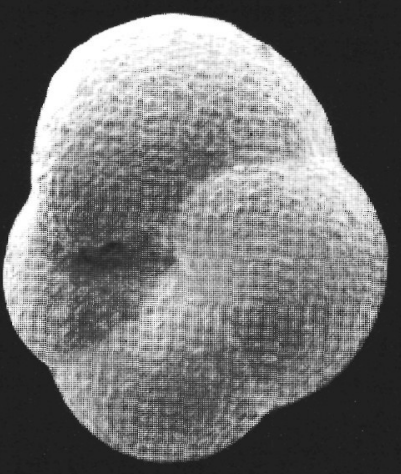

4

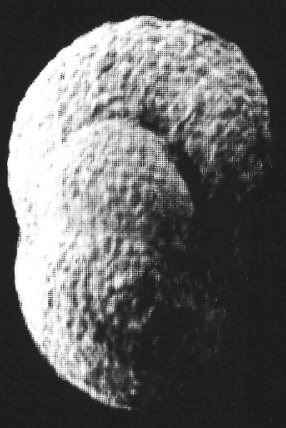

5

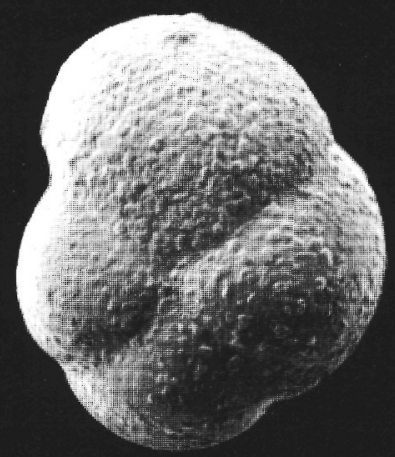

6
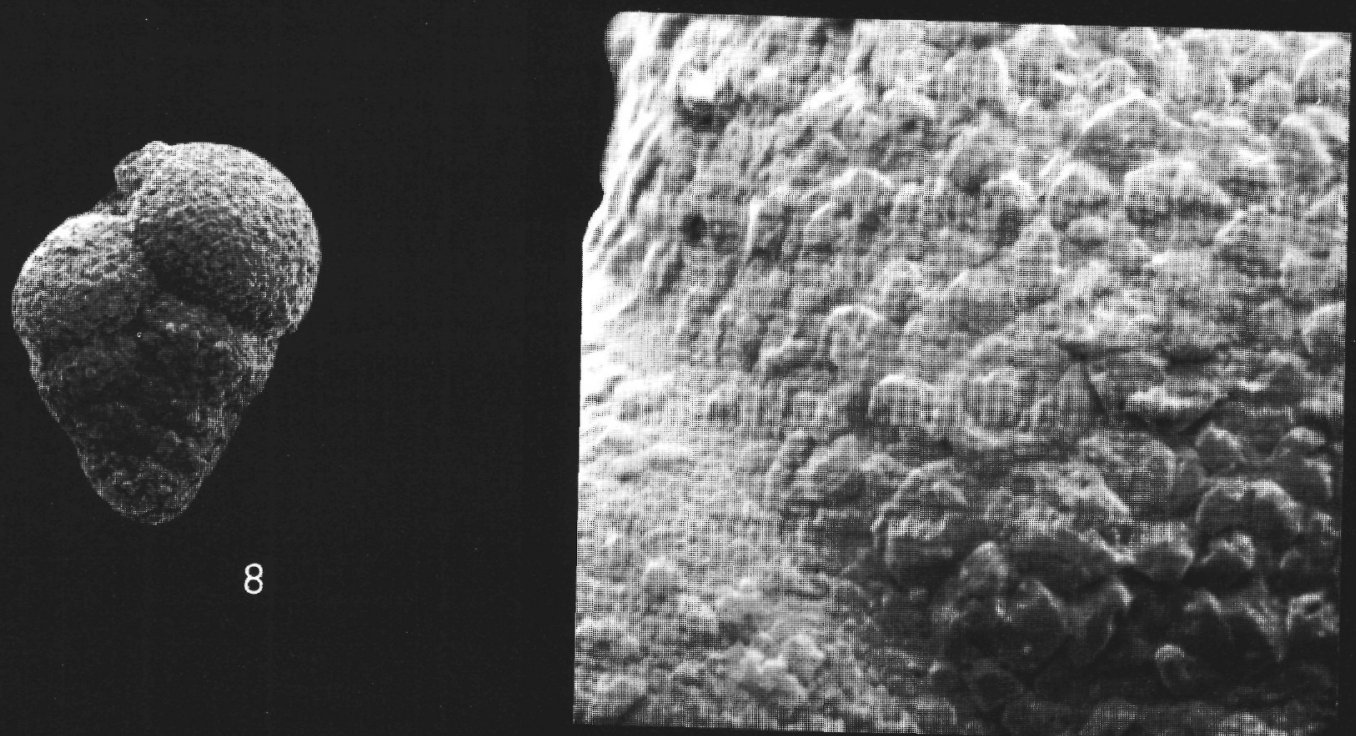
Figures 1-3 Bolivina sp.

The test of this small species is moderately compressed, with rounded edges. Basal margins of the chambers are lobed, but this is obscured by heavy ornament except where the later chambers of the test are smoothly granular. The ornamentation consists of a reticulate pattern of raised ridges that coalesce with those of the earlier chambers of the test across the chamber lobes. The ridges tend to be frilled over the earlier portion of the test and are of high relief relative to the size of the test. This species occurs in the late Eocene to early Oligocene section at Site 321, where it disappears at a facies change. As it does not occur in the late Oligocene section at Site 320, early Oligocene appears to be the upper limit of its range.

1. Sample 321-13-1, 100-102 cm, late Eocene. Length of specimen $0.21 \mathrm{~mm}$.

2. Sample 321-13-1, 100-102 cm, late Eocene. Length of specimen $0.20 \mathrm{~mm}$.

3. Sample $321-9-1,114-116 \mathrm{~cm}$, early Oligocene. Length of specimen $0.26 \mathrm{~mm}$.

Figure 4 Bolivina cf. gladius Garrett. Sample 320-2-1, 84-86 cm, early Miocene. Length of specimen without spine $0.36 \mathrm{~mm}$. The illustrated specimen has particularly well-developed costae, peripheral keels in the early portion of the test, and basal spine. This represents the same species as B. cf. gladius of Parker (1964), also occurring in strata of Miocene age.

Figure 5 Bulimina alazanensis Cushman. Sample 321-13-1, 100-102 cm, late Eocene. Length of specimen (without spine) $0.23 \mathrm{~mm}$.

Figure 6 Bulimina sp. B, Sample 320B-2-5, 108-110 cm, late Oligocene. Length of specimen $0.18 \mathrm{~mm}$. The test consists of four or five volutions of chambers that are somewhat twisted and gradually increase in size as added. All but the last volution is ornamented with low costae, four or five per series of chambers. The costae bifurcate on the first or second volution of the test and are attached only to the base of the last volution of chambers. This species may have been overlooked in previous studies because of its small size. It occurs in the Oligocene and early Miocene portion of the Nazca section.

Figure 7 Bulimina impendens Parker and Bermúdez, Sample 321-13-1, 100-102 cm, late Eocene. Length of specimen $0.21 \mathrm{~mm}$. This species, originally described from Eocene strata of Cuba, is characterized by strongly overlapping chambers that are frilled at their bases and by numerous projecting spines in the early portion of the test. The illustrated specimen typifies the development of the species in the Nazca material, although an occasional specimen develops an additional volution of chambers. The species ranges from Eocene through the Oligocene.

Figure 8 Bulimina sp. A, Sample 321-13-3, 30-32 cm, late Eocene. Length of specimen $0.46 \mathrm{~mm}$. Considerable variation was noted in the coarseness of the ornament and the amount of twist to the test of this species. However, all specimens had a well-developed basal spine. The illustrated specimen presents an immature individual with coarse ornament consisting of sinuous, bifurcating and cross-connected costae. A larger individual $(0.60 \mathrm{~mm})$ was found in which the ornament was weak and the later chambers did not continue to expand in size. This species most closely resembles $B$. semicostata Nuttall, but the variation of ornament and the basal spine appear to be distinctive. It occurs only in the Eocene.

Figure 9 Buliminella grata Parker and Bermúdez, Sample 321-13-3, 30-32 cm, late Eocene. Length of specimen $0.27 \mathrm{~mm}$. View showing sutural lobes. The species ranges through the Oligocene in the Nazca material.

Figures 10,11 Uvigerina ciperana Cushman and Stainforth. The species is small and slender, with later chambers becoming somewhat loosely coiled. The chambers are distinct and are ornamented with longitudinal costae that tend to disrupt into spines in some specimens. This species was found in late Oligocene and early Miocene strata at Site 320.

10. Sample 320B-1-5, 30-32 cm, early Miocene. Length of specimen $0.32 \mathrm{~mm}$.

11. Sample 320B-2-5, $108-110 \mathrm{~cm}$, late Oligocene. Length of specimen $0.32 \mathrm{~mm}$.

Figure 12 Siphonodosaria abyssorum (Brady) var. aculeata (Cushman and Renz), Sample 321-13-1, 100-102 cm, late Eocene. Length of specimen $1.17 \mathrm{~mm}$. All specimens attributed to the species had several spines at the base of the test. The illustrated specimen shows additional spines at the bases of the chambers, as occur in the variety. The range of the variety was noted to be at least through the lower Miocene (N.8) on the Nazca plate. Modern specimens of the species were present in Challenger material from a water depth of about 3650 meters. 


\section{PLATE 2}

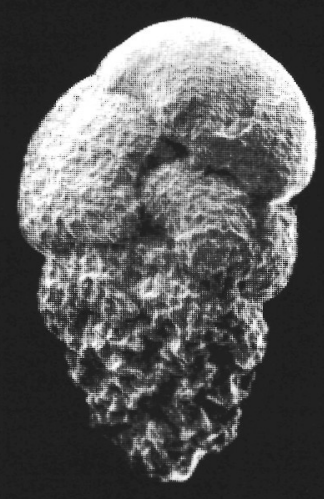

1

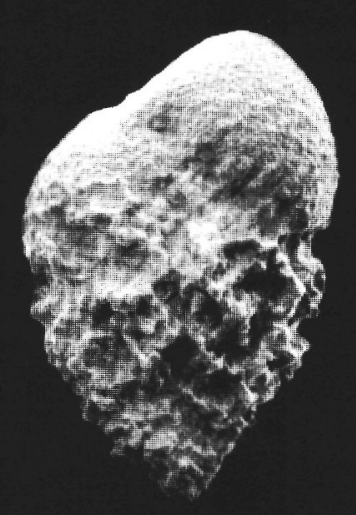

2

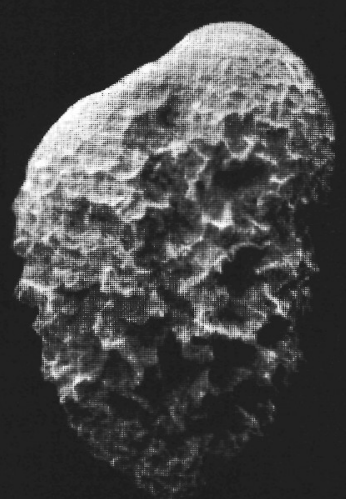

3

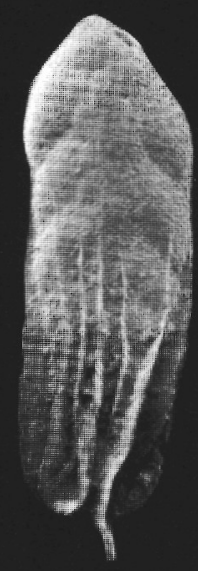

4

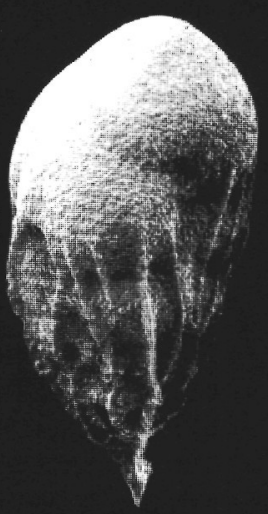

5

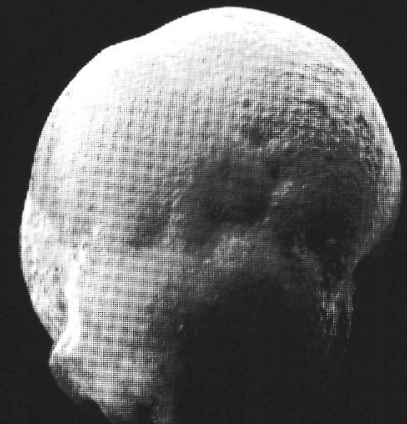

9

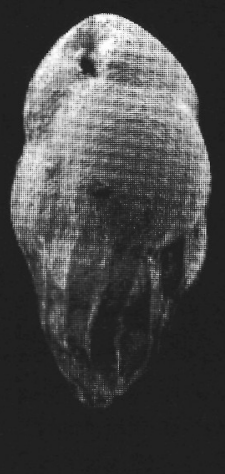

6

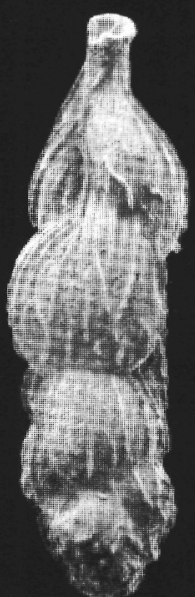

10

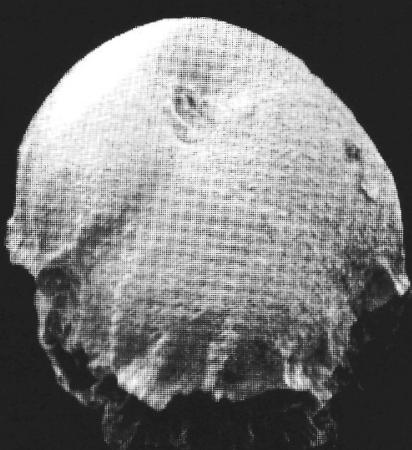

7

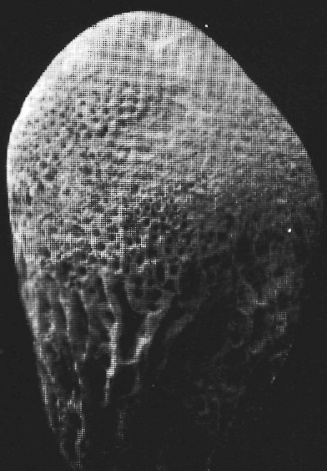

8
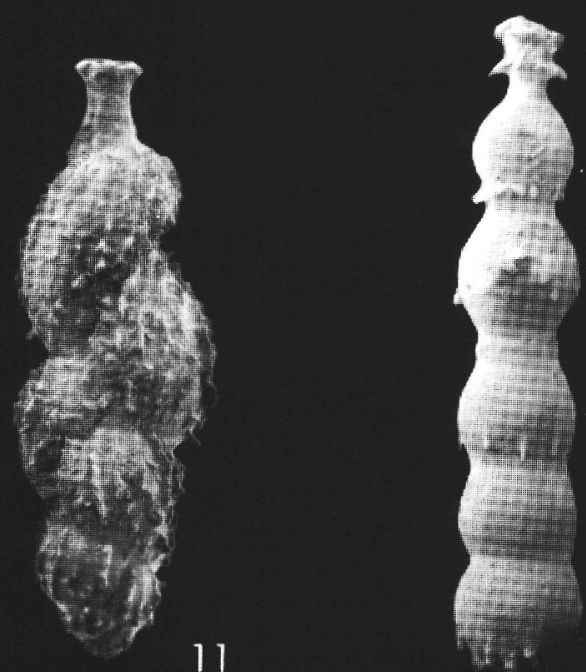

11 


\section{PLATE 3}

Figure 1

Figures 2, 3

Figures 4, 5

Figures 6, 7

Figures 8,9

Figures 10,11 Nuttallides truempyi (Nuttall). The test is biconvex, but more convex on the ventral side than dorsally. The oblique sutures may be lobed ventrally toward the large ventral umbo of clear shell material. This species occurs only in the late Eocene portion of the Nazca section.

10. Sample 321-13-3, 30-32 cm, late Eocene. Ventral view, maximum diameter $0.40 \mathrm{~mm}$.

11. Sample 321-13-1, 100-102 cm, late Eocene. Dorsal view, maximum diameter $0.67 \mathrm{~mm}$. 
PLATE 3
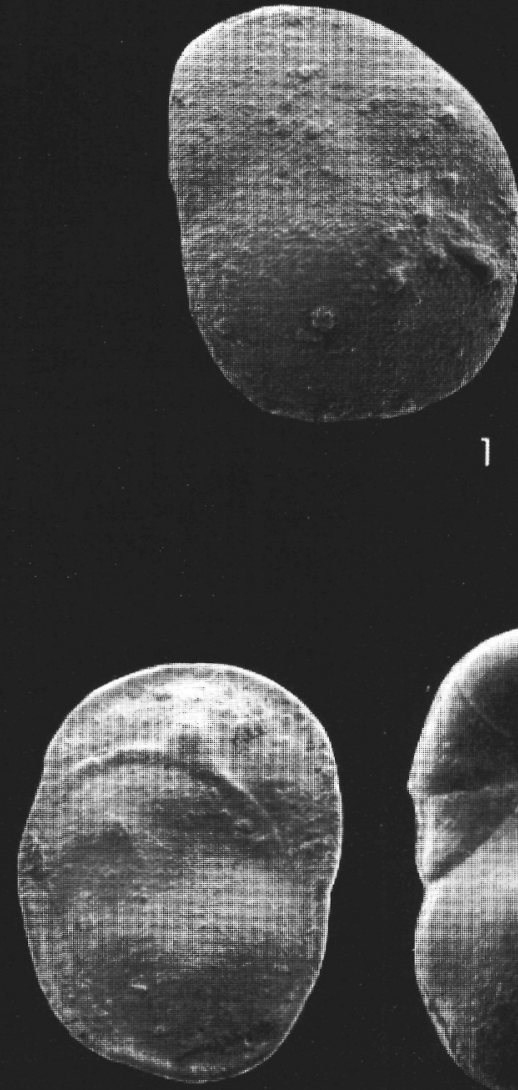

4

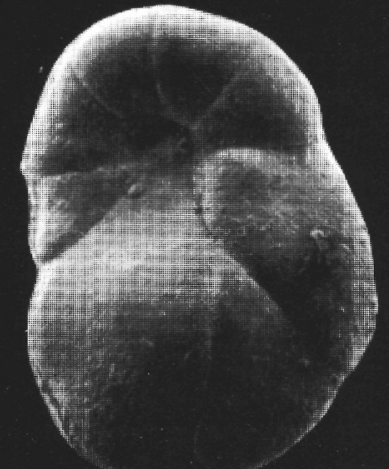

5

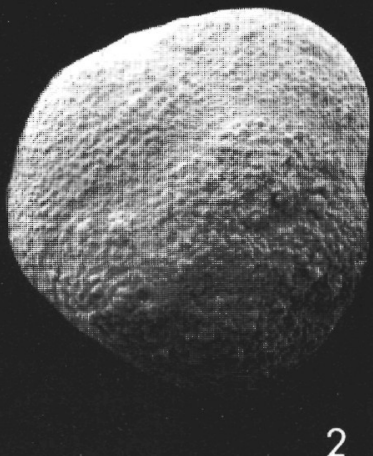

2
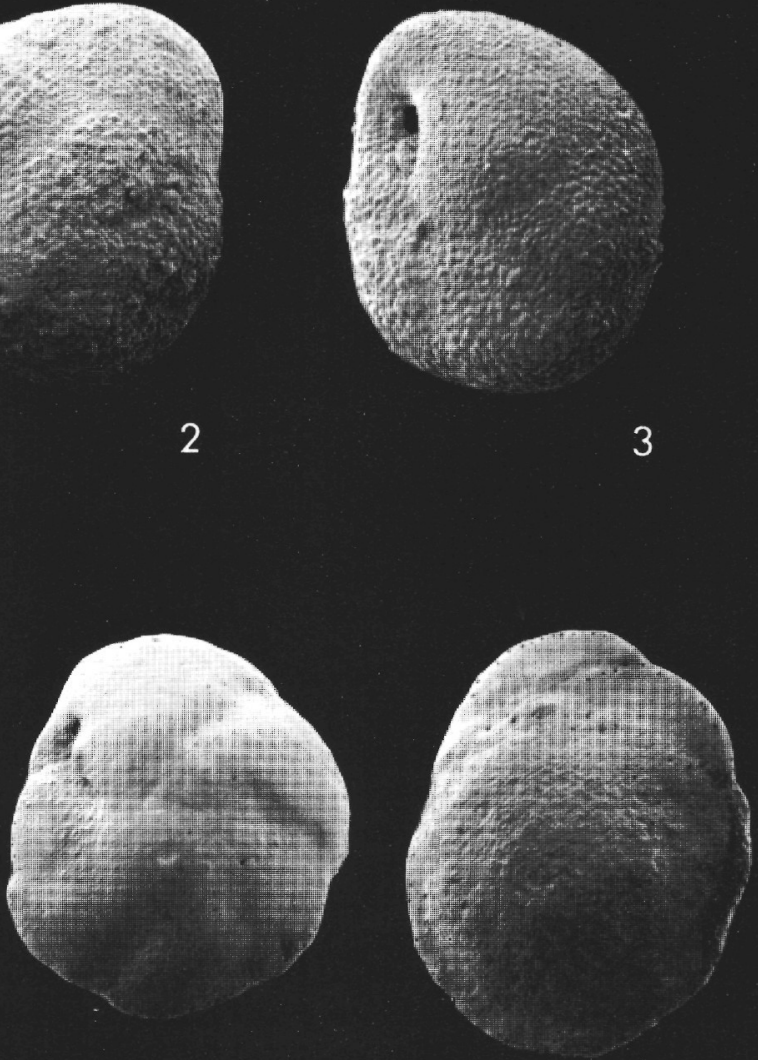

6
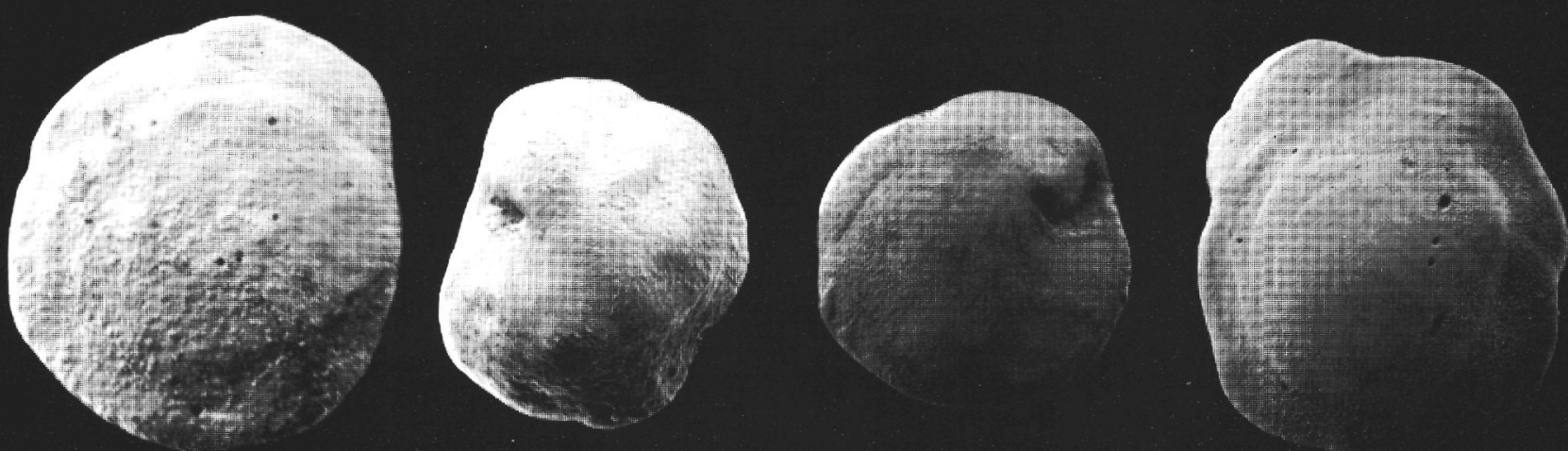

8

9

10

11 


\section{PLATE 4}

Figures 1,2 Cibicidoides bradyi (Trauth). Chambers of the later volutions tend to overlap the spiral suture in this species, which also may be identified by its amber-colored test. Brady's (1884) modern specimen was from a water depth of about 3800 meters.

1. Sample 320-2-1, 84-86 cm, early Miocene. Dorsal side, maximum diameter $0.40 \mathrm{~mm}$.

2. Sample 320-3-1, 104-106 cm, early Miocene. Ventral side, maximum diameter $0.34 \mathrm{~mm}$.

Figures 3,4 Cibicidoides havanensis (Cushman and Bermúdez). This species was found in late Eocene to early Miocene strata of the Nazca plate.

3. Sample 321-13-3, 30-32 cm, late Eocene. Dorsal side, maximum diameter $0.70 \mathrm{~mm}$.

4. Sample 321-9-1, 114-116 cm, early Oligocene. Ventral side, maximum diameter $0.68 \mathrm{~mm}$.

Figures 5-7 Allomorphinella? sp. Sample 321-13-1, 100-102 cm, late Eocene. The test is compressed, planispiral, and involute, with three chambers per volution; the sutures not exactly symmetrical on both sides of the test, as in the type species of $\mathrm{Al}$ lomorphinella. The aperture is an equatorial arch on an overhanging projection of the test. Perforations are not obvious in the wall, which nevertheless appears to be secreted and contains some larger granules. This species)occurs only in the late Eocene portion of the section.

5. Side view, maximum diameter $0.20 \mathrm{~mm}$.

6. View of opposite side, maximum diameter 0.23 $\mathrm{mm}$.

7. Detail of wall of specimen in Figure 6, $\times 1700$.

Figures 8,9 Alabamina dissonata (Cushman and Renz), Sample 321-13-3, 30-32 cm, late Eocene. Note the oblique, limbate and slightly raised sutures of this Eocene index.

8. Ventral view, maximum diameter $0.33 \mathrm{~mm}$.

9. Dorsal view, maximum diameter $0.45 \mathrm{~mm}$.

Figures 10, 11 Anomalinoides sp. 1 of Douglas (1973).

10. Sample 320-3-1, 104-106 cm, early Miocene. Dorsal view, maximum diameter $0.28 \mathrm{~mm}$.

11. Sample $320-2-1,84-86 \mathrm{~cm}$, early Miocene. Ventral view, maximum diameter $0.35 \mathrm{~mm}$. 


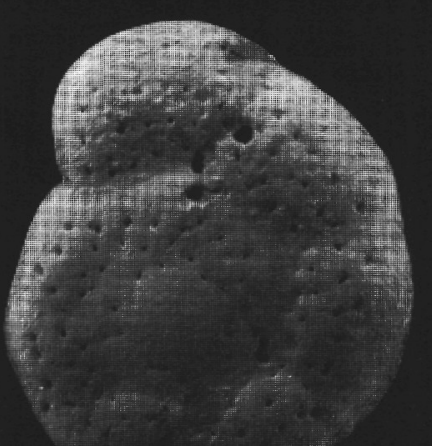

1

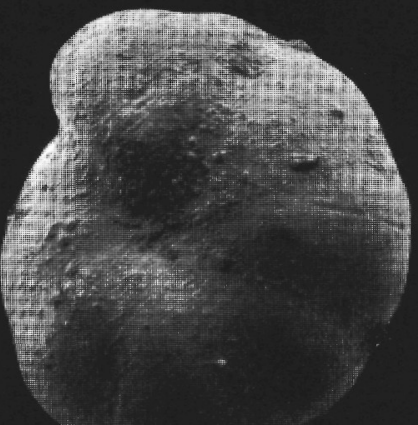

2

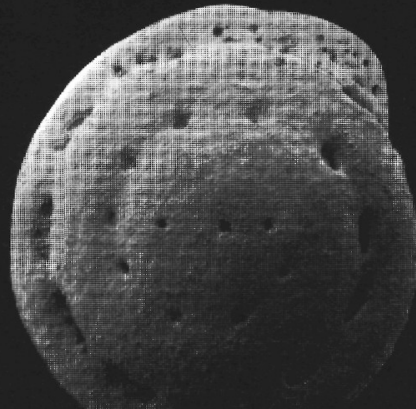

3

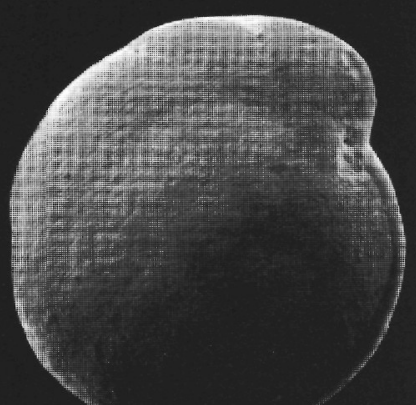

4

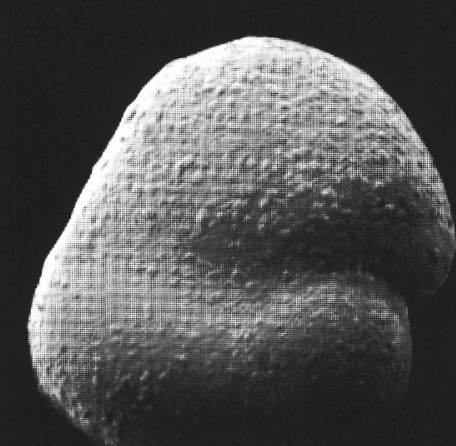

5

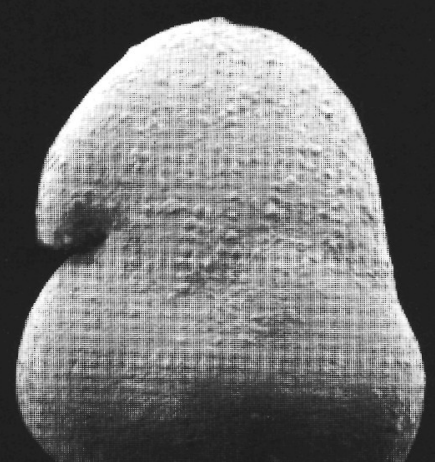

6

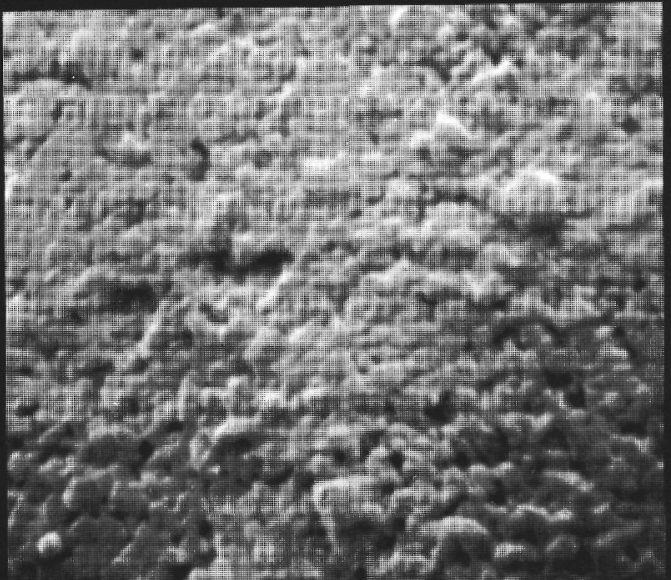

-a.1. Fat

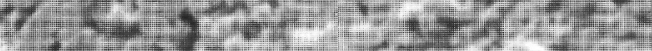

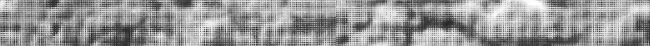
4-a 7 a

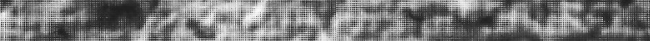

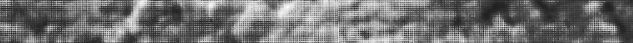

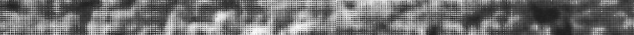

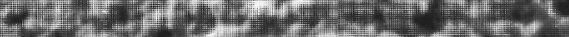

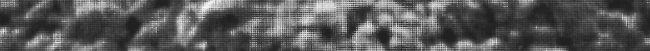

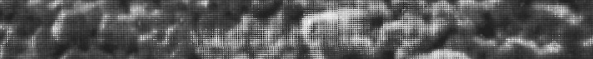

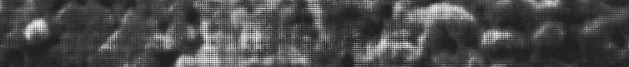

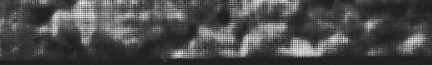

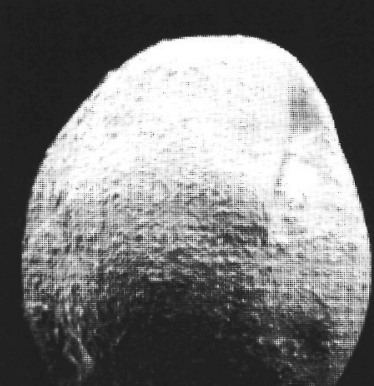

8

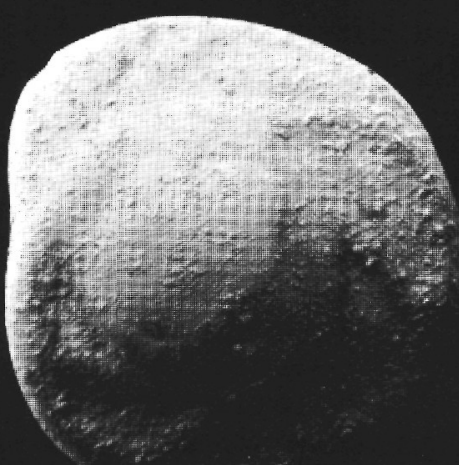

9

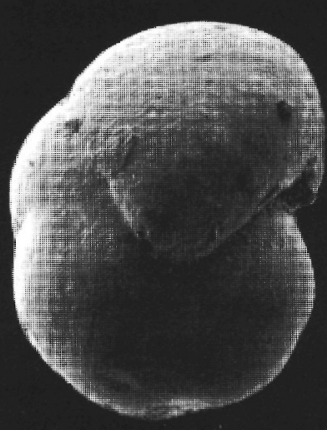

10

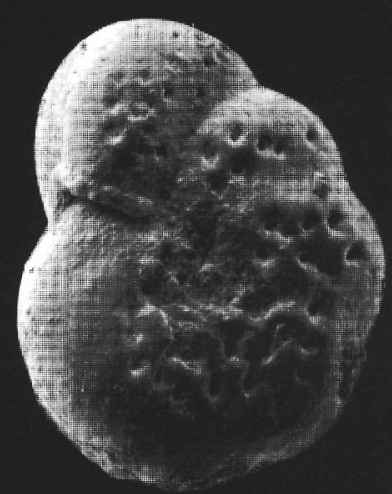

11 